УДК 37.014.523

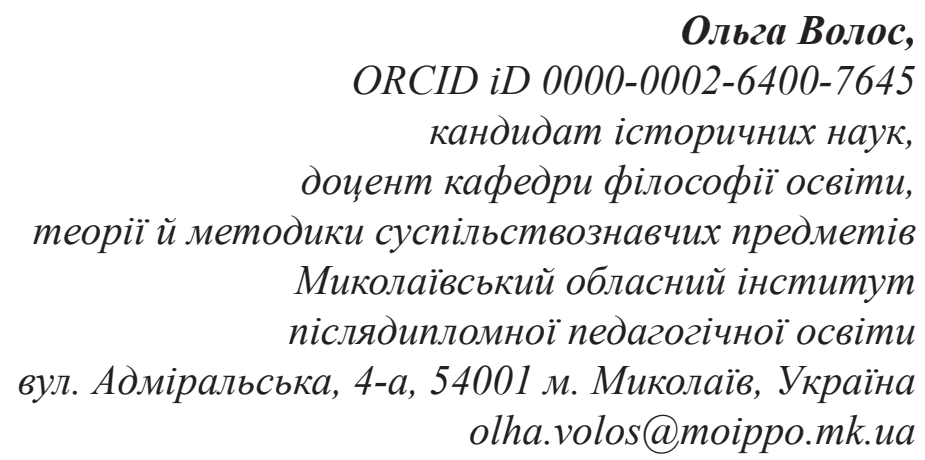

\title{
ШКІЛЬНА РЕЛІГІЙНА ОСВІТА НА ТЕРЕНАХ ПІВДЕННОЇ УКРАЇНИ ПРОТЯГОМ ХІХ СТОЛІТТЯ
}

У статті розглядається питання викладання «Закону Божого» в системі народної освіти на теренах України. Аналізується структура курсу та окремі методичні аспекти викладання. 3'ясовується державна політика щзодо впровадження «Закону Божого» в навчальний прочес протягом XIX століття. Розкривається земська політика щзодо релігійної освіти та виховання. Висвітлюється думка передової педагогічної громадськості України відносно означеної проблеми. Досліджується джерельна база означеної проблеми.

Ключові слова: Закон Божий; законовчитель; земство; народна школа; педагогічна громадськість; південна Украӥна.

(C) Волос О. В., 2021

Вступ. Дослідження минулого вітчизняної освіти дає можливість глибше виявити наявний історичний досвід, передбачити основні тенденції іï розвитку в майбутньому. Вивчення досвіду становлення і розвитку шкільної освіти та системи виховання на теренах південної України дозволяє виявити та розглянути характерні особливості означеного процесу в регіоні в історичних рамках XIX - початку XX століть, збагатити історію педагогіки як методологічно, так і фактично.

Серед питань, що належать до аналізованої проблеми, хотілось би звернути увагу на релігійну складову освіти і виховання у світських навчальних закладах Херсонської губернії та участь у цьому процесі духовенства.

Зростання інтересу до історико-культурної спадщини південного краю, формування регіональної шкільної політики та незначна кількість публікацій із зазначеної проблеми зумовили звернення автора до

Вересень № 1 (88) 2021 названої вище теми дослідження.

Метою публікації $\epsilon$ аналіз навчального процесу, викладання предметів релігійного змісту в системі народної освіти Півдня України протягом XIX ст. і з'ясування ролі місцевих органів самоврядування в процесі релігійного виховання населення краю.

Серед завдань розвідки - аналіз наявної джерельної бази та літератури з досліджуваної проблеми, визначення досвіду запровадження в навчальний процес предметів релігійного змісту.

Виклад основного матеріалу. Відповідно до характеру збереженого фактичного матеріалу і методологічних принципів його наукового аналізу в історії дослідження розвитку освіти можна виділити три основних етапи досліджень: 1) дореволюційний (XIX ст. - 1917 р.); 2) радянський (із 1917 до 1991 рр.); 3) сучасний (із початку 90-х років ХХ ст. до сьогодення).

Працям першого періоду притаман- 
ний поділ на «світську» і «духовну» освіту. Стан і розвиток світської школи оцінюється в фундаментальних працях В. Григор'єва (Григорьев В., 1900), П. Каптерева (Каптерев П., 1909), С. Рождественського (Рождественский С., 1912). Історія земської школи стала предметом зацікавленості Б. Веселовського (Веселовский Б., 1909), В. Чарнолуського (Чарнолуский В., 1911). Серед публікацій про зміст освіти та систему виховання в навчальних закладах розглядуваного періоду варто назвати дослідження А. Анастасієва (Анастасиев А., 1915). Історія церковнопарафіяльної школи вивчалася переважно в працях з історії церкви. Так С. Миропольський (Миропольский С., 1895), А. Ванчаков (Ванчаков А., 1908, с. 47-49), І. Восторгов (Восторгов И., 1911) обгрунтовують необхідність існування церковної школи та високо оцінюють внесок духовенства в справу народної освіти. Здебільшого роботи як світського, так i церковного напрямів мали описовий характер, доволі часто в них немає будь-якого аналізу, проте вони інформативні, містять великий статистичний та фактографічний матеріал. У цей же період з'являються роботи регіонального рівня. На особливу увагу заслуговують дослідження, що присвячені становленню та розвитку мережі закладів освіти в Херсонській губернії, зокрема брошури та монографії В. Фармаковського (Фармаковский В., 1990), А. Конощенка (Конощенко А., 1908), А. Пашутіна (Пашутин А., 1897), М. Корфа (Корф Н., 1870), у яких подається структура навчальних закладів, система їхнього управління, організація навчального процесу тощо.

Наукові праці радянського періоду вирізняє негативна оцінка державної політики, що проводив царський уряд у галузі народної освіти. Серед негативних характеристик дореволюційної системи освіти перелічувалися: хаотичність, багатоманітність типів шкіл, становість, нерівноправність жінок і національних меншин, низький рівень охоплення дітей початковою освітою. Характеризуючи радянську систему освіти, науковці акцентували, що вона була створена не реформуванням старої системи, а через іiї ліквідацію та створення нової. Серед великої кількості наукових праць другого періоду доречно згадати роботи С. Каменєва (Каменев С., 1929), М. Константинова (Константинов Н., 1953), С. Сгорова (Егоров С., 1978, c. 22-37), І. Богданова (Богданов И., 1964), М. Гриценка (Гриценко М., 1973), а також праці, які висвітлюють проблеми регіональної дореволюційної освіти - П. Нестеренка (Нестеренко П., 1930), А. Готалова-Готліба (Готалов-Готлиб А., 1925). Отже радянські вчені досліджували й аналізували політику царського уряду щодо освіти, системи роботи шкіл, динаміки зростання контингенту учнів, розвитку передової педагогічної думки, досвіду роботи окремих шкіл та їхнього матеріального забезпечення.

Сучасний стан розроблення науковцями означеної проблеми свідчить про інтерес до неї, який постійно зростає. За роки незалежної України виконано чимало дисертаційних досліджень, видані монографiї, у яких автори аналізують питання освіти в досліджуваний період із національно-культурних позицій, характеризують роль держави, земств, Святішого Синоду в ліквідації неписьменності населення України. Позитивним $є$ також те, що дослідники дають аргументовану характеристику розвитку школи в окремих регіонах нашої країни. Помітним внеском серед регіональних досліджень варто назвати праці В. Боброва (Бобров В., 2001), I. Добрянського, В. Постолатія (Добрянський I., Постолатій В., 1998). Автори цих досліджень вказують, що зростання економічного потенціалу на Півдні України сприяло розвитку мережі закладів освіти у пореформений період та зростанню популярності освіти серед населення південного регіону.

Історіографічний аналіз досліджень, присвячених розвитку релігійної та світської освіти на теренах України до 1917 року, показує, що поза увагою наукової громадськості залишилися доволі важливі питання, зокрема питання історичних 
традицій викладання релігійних знань, які склалися в школах, форм проведення занять із Закону Божого, контролю за навчальним процесом та його кадрового забезпечення.

Історія світської школи в Російській імперії бере свій початок в епоху реформ Олександра II, що почалася після скасування в 1861 році кріпосного права. У цей час виникла ідея створити новий тип школи, яка відповідала б вимогам часу, тому що стара церковна школа через обмеженість навчальних предметів не відповідала практичним інтересам держави. Урядові шкільні реформи (1864, 1874 рр.), навіть незважаючи на їхню половинчастість, незавершеність і суперечливість, сприяли розширенню мережі народних шкіл. Головною проблемою уряду був брак коштів на цю справу, тому відповідальність за утримання шкіл була покладена на народ.

Важливою подією в історії держави середини 60-х років XIX ст. стало створення земських установ, які взяли на себе вирішення багатьох організаційних, кадрових і фінансових проблем народної освіти. Незважаючи на дії уряду щодо регламентування та обмеження, органи місцевого самоврядування поступово взяли на себе функції з відкриття нових шкіл, підтримки наявних, вирішення кадрових питань, навчально-методичного забезпечення освітнього процесу. Земська школа вимагала менше фінансових витрат і більшою мірою була наближена до практичних потреб народу.

В освітніх питаннях права земств вичерпувалися такими пунктами:

- утримання шкіл, подання звітності про фінансові витрати;

- рекомендація кандидатів на вчительські посади;

- вибори попечителів училищ, які утримувалися за рахунок земств;

- участь, хоча і незначна, у діяльності училищних рад (2 земські представники).

Піклування про початкову освіту було віднесено до компетенції повітових земств, які повинні були дбати лише про забезпечення народних шкіл. Впливати на навчально-виховний процес цим органам самоврядування заборонялося. На той час шкільна справа в Російській імперії не мала сталої системи, школи були у значному занепаді, підручників не було, навчання велося безсистемно, учителі не мали відповідної підготовки. Та й перші земські діячі не уявляли, яким має бути характер народної школи.

До 90-х років XIX ст. на організацію шкіл земства виділяли гроші спільно з сільськими громадами, які до створення земств відкривали в окремих селах лише школи грамоти.

Спочатку земська школа була однокласною з трирічним курсом навчання, а на початку XX ст. відкриваються училища 3 чотирирічним курсом, а подекуди - i 3 п'ятирічним та шестирічним курсом навчання. У них навчали читати, писати та рахувати. Оскільки земські школи були в підпорядкуванні міністерства народної освіти, то програми, навчальні посібники та підручники визначалися ним.

Кошти, що виділялися земствами на потреби шкільництва, поступово зростали. Так, на Херсонщині у 1865 році на початкові школи асигновано 6285 крб, із яких за звітом губернської управи використано лише 3160 крб у зв'язку з тим, що не виявилося ні шкіл, які би потребували підтримки, ні учнів, яким необхідна була допомога; ні вчителів, гідних заохочення й піклування про них. А вже через 30 років Херсонське земство взяло на себе третину всіх витрат на школу (Волос О., 1996, c. 19). Отже п'ять українських губерній (Катеринославська, Полтавська, Харківська, Херсонська, Чернігівська) у 1895 році внесли в кошторис на народну освіту понад півтора мільярда крб (Веселовский Б. 1909, c. 475-476).

Протягом існування земської школи їй увесь час намагалися перешкоджати:

- у 60-70-х роках міністерство народної освіти, яке, маючи на меті перехопити ініціативу земств, починає створювати власні початкові 
школи та посилює інспекцію;

- наприкінці 80-х - початку 90-х рр. Державна Рада починає кампанію передавання шкіл до одного відомства - у підпорядкування Синоду.

Із дозволу міністра народної освіти й обер-прокурора Синоду Д. Толстого духовенство починає відкривати церковнопарафіяльні школи. Слід зазначити, що в основі навчального процесу парафіяльних шкіл була дисциплінарна система, яка стала: «... частиною виховного процесу, заснованого на релігійних принципах. У всіх школах правила поведінки і покарання були побудовані за загальним зразком, але були й деякі відхилення від правил... Значну роль при цьому відігравала особистість учителя» (Шафрановський В., Фазан В., 2021, c. 83-84). Згодом асигнування на цю справу зростають, і в 1911 р. в Україні від загальної кількості початкових шкіл нараховувалося 8465 церковнопарафіяльних шкіл, що становило 42,5 відсотка. Земських було 5403 школи, тобто 27,1 відсотка. На початку XX ст. земства починають створювати школи вищого типу (двокласні початкові). Перша така школа створена на Катеринославщині Олександрівським повітовим земством, що мала ім'я Миколи Корфа, видатного земського діяча, педагога, організатора земських шкіл, який започаткував учительські з'їзди (своєрідні літні курси підготовки вчителів), які проходили спочатку в Катеринославській, Херсонській, а згодом і в інших губерніях (Корф Н., 1878, c. 20).

Для завідування двокласними школами створювалися два колегіальні органи:

- опікунська рада (до її складу входили обрані повітовими земськими зборами почесний спостерігач та два члени ради - завідувач школи та голова повітової земської управи), що відповідала за господарську діяльність;

- педагогічна рада (завідувач школи, законовчитель, викладачі та члени опікунської ради), яка займалася навчально-виховними процесом.
Із відкриттям двокласних шкіл необхідно було створити й нові програми. Трирічна школа на той час була простою школою грамоти, за шкільними програмами не передбачалося повідомлення учням найелементарніших наукових знань.

У 1910-1911 роках розроблені нові програми, які, як зазначалось у пояснювальній записці, повинні були ознайомити учнів із вітчизняною історією, географією, дати школярам елементарні відомості про явища природи, навчити азів арифметики. Проєкт навчального плану 1913 року, порівняно з планом 1897 року, передбачав зменшення кількості годин для викладання предметів релігійного змісту, які становили 45 відсотків усього навчального часу. За новим навчальним планом співи були не лише церковними, а й світськими. Це становить 24 відсотки всього чотирирічного курсу навчання.

Зазначимо, що такі предмети, як історія, географія, природознавство, уважалися необов'язковими в початковій школі. Нові навчальні плани і програми в Україні розроблялися протягом 1910-1915 років представниками органів земського та міського самоврядування, різними вчительськими товариствами та курсами, а також передовими педагогічними діячами.

Софія Русова в статті «Нова школа», що опублікована в журналі «Світло», писала: «... в українській початковій школі повинні вивчатися такі предмети: Закон Божий, рідна мова, арифметика, природознавство, географія, ручна праця (малювання, ліплення, різьблення по дереву), співи, фізичне виховання» (Русова С., 1914, c. 13-14).

Яків Чепіга (родом із Херсонської губернії, закінчив Ново Бузьку вчительську семінарію) на заклик журналу «Світло» у 1913 році розробив «Проект української школи» (Чепіга Я., 1914, с. 20), за яким передбачалася двоступенева початкова школа із загальним шестирічним терміном навчання. Перший ступінь (2 роки) - це підготовка до школи, розвиток дитячої свідомості, ознайомлення $з$ оточенням 
і навколишнім життям. Програма містила ігри, забави, прогулянки, працю на городі, у полі, догляд за домашніми тваринами, ліплення, прилучення до природи, казки, пісні в невимушеній обстановці.

На другому ступені навчання протягом чотирьох років школа мала розвивати дитячу самодіяльність, творчу індивідуальність. Зміст навчання передбачав вивчення: рідної мови; арифметики; природознавства; історії, географії; російської мови (на 5-6 році навчання); ручної праці.

Згідно з правилами «зразкових програм предметів, що викладали у початкових народних школах», законовчитель мав у кожному класі (де учнів було не більше 45) по 6 годин на тиждень, не рахуючи 3 години на церковний спів. Учителі мали на тиждень 18 годин (каліграфія, читання, арифметика та інші предмети), співи 3 години, робота $з$ учнями, що відстають у засвоєнні програми, та перевірка учнівських зошитів. Отже, за найпростішим розрахунком третина годин, що відводилися на тиждень у початковій школі, призначалася для вивчення Закону Божого, який за наказом 1804 року був обов'язковим серед предметів церковнопарафіяльних шкіл, а згодом і в інших народних школах, у подальшому 3 числа основних предметів не вилучався. У 1880 році на губернських земських зборах у Херсонській губернії прийняли рішення про преміювання законовчителя за викладання Закону Божого в початковій школі по 1 крб за 2 год (не більше 50 крб на рік).

Якщо взяти до уваги середню освіту, то історія викладання Закону Божого не була послідовною. Згідно з Імператорським повелінням 1812 року Закон Божий був внесений у перелік обов'язкових предметів гімназій. Цьому передувало розроблення попечителем Санкт-Петербурзького навчального округа графом С. Уваровим альтернативної програми гімназійної освіти, у якій велику увагу приділяли Закону Божому, стародавнім мовам та словесності.

У 1823 році надрукували Православний Катехізис, складений митрополитом Філаретом. Він став основним навчальним посібником із Закону Божого для середніх навчальних закладів усіх ступенів. Катехізис слугував основою для складання програми з цього предмета.

Виданий 8 грудня 1828 року новий Статут про середні навчальні заклади передбачав серед обов'язкових предметів i Закон Божий. За цим Статутом програма Закону Божого в гімназії передбачала вивчення:

- священної історії Ветхого і Нового Завіту - в 1 та 2 класах;

- розширеного Катехізису - у 3-4 класах ;

- церковної історії та Священного письма - у 5-6 класах;

- обов'язків християнина у 7 класі.

У 1851 році програма зазнала змін, у 1-2 класах додавалося вивчення короткого курсу Катехізису та повторення і роз'яснення основних молитов, а у 7 класі - замість обов'язків християнина викладалося вчення про богослужіння, а також повторювався загальний курс Закону Божого. Отже, на середину XIX ст. предмет уже мав своє оформлення.

Складові частини курсу розподілялись із урахуванням вікових і психологічних особливостей учнів. Під час викладання застосовували міжпредметні зв'язки 3 курсами російської мови і літератури, вітчизняної і зарубіжної історії, психології та логіки.

Предмет посідав перше місце в програмі не тільки тому, що з нього починали перевідні та вступні іспити, він був стрижнем усього процесу викладання, навчальний рік і тривалість канікул залежали від річного кола православних свят, зміст яких пояснювався на уроках.

За повелінням імператора (від 17 січня 1829 року) законовчителя призначали залежно від віросповідання учнів, хоч гімназії і визнавалися християнськими навчальними закладами.

Повертаючись до початкової школи на Україні, де предмет викладався церковнослов'янською або російською мовами, зауважимо, що засвоєння курсу учнями 
було здебільшого проблематичним, оскільки учні не завжди розуміли, про що розповідає законовчитель.

Прогресивні педагогічні діячі України та представники земських органів самоврядування відстоювали необхідність навчання в початковій школі на перших порах рідною мовою, що сприяло б підвищенню успішності (Сірополко С., 1910, с. 12; Черниговец, 1904, с. 15; Гринченко Б., 1906, c. 14; Земская хроника, 1901; Справа народної освіти на Україні, 1911, с. 52; Документы, известия и заметки, 1905, с. 23-27). Учителі та законовчителі початкових шкіл мали надію, що 3 виданням українською мовою Свангелія процес викладання цього предмета полегшиться.

На з'їзді отців законовчителів, що відбувся 1910 року в Почаєві, багато делегатів рішуче висловлювались як за навчання в народній школі українською мовою взагалі, так і за викладання нею Закону Божого зокрема, оскільки школярі однаково погано розуміють і російську, і церковнослов'янську. Із цього погляду великою подією вважалося благословення у 1905 році Святішим Синодом закінчення роботи над перекладом українською мовою Євангелія, що, хоча і опосередковано, зрівняло в правах українську мову з тими, на які вже була перекладена Священна книга. Факт виходу синодального видання українського Свангелія давав педагогам певну надію на дозвіл використання його в школі, а це автоматично викликало необхідність навчання рідної грамоти - адже книгу треба було якось читати. Але офіційного дозволу щодо вживання в школі перекладеного Євангелія не надійшло, тому деякі священники самочинно роздавали його дітям, за що потерпали від шкільного начальства (Гетьманчук Я., 1911, с. 59).

До утворення земств бібліотечної мережі на селі не було і тільки земські управи розпочали справу з організації народних та шкільних бібліотек, що були безкоштовними. До лютого 1906 року діяли обмеження в комплектуванні бібліотек, і тільки з цього часу до них почали надходити українські книжки. Книжки в бібліотеках, які здебільшого рекомендовані духовенством, були переважно російською мовою, зокрема: «Вибране життя Святих, чудотворців і мучеників», «Святого Інокентія Богоносця», «Абіссинія - християнська країна», «Амур - край хрещеного світу».

Усі ці факти свідчать про те, що протягом XIX століття формування змісту та впровадження шкільного предмета «Закон Божий» відбувалися відповідно до розвитку та становлення в державі багатоступеневої освіти і на різних етапах іiі історії цей процес корегувався та зазнавав змін. Щодо виборних органів місцевого самоврядування, то земства в школах, які були в їхньому підпорядкуванні, протягом останньої третини XIX століття утримували законовчителя своїм коштом і сприяли тому, щоби викладання предмета «Закон Божий» було зрозумілим для школярів. Проте протягом досліджуваного періоду шкільний предмет «Закон Божий» із навчального процесу не вилучався.

Перспективою подальшого дослідження $\epsilon$ вивчення стану викладання «Закону Божого» в школах на початку XX ст. у межах українських земель та вилучення його $з$ переліку шкільних предметів.

\section{ЛІТЕРАТУРА}

1. Анастасиев А. Народная школа: Руководство для учителей и учительниц / А. Анастасиев. - М., 1915. - 581 с.

2. Бобров В. Становлення та розвиток ліцеїв і гімназій Півдня України (XIX - поч. ХХ ст.) / В. Бобров. - Херсон, 2001. - 250 с.

3. Богданов И. Грамотность и образование в дореволюционной России и СССР (историко-статистические очерки): Статистика / И. Богданов. - М.: 1964. - 195 с.

4. Ванчаков А. Заметки о начальной церковной школе (Ввиду проекта закона о всеобщем обучении) / А. Ванчаков. - СПб., 1908. - С. 47-49. 
5. Веселовский Б. История земств за сорок лет / Б. Веселовский. - Т. 1. - Спб., 1909. $-724 \mathrm{c}$.

6. Волос О. Роль повітових земств Херсонської губернії в становленні народної освіти нашого краю (60-ті роки XIX - поч. ХХ ст.) / О. Волос // Вересень. - 1996. № 1. - С. 19.

7. Восторгов И. Государственная Дума и церковные школы. Бесплатное приложение к ж-лу «Народное образование» за сентябрь 1911 г. / И. Восторгов. - СПб., 1911. - 40 с.

8. Гетьманчук Я. Наші сподівання / Я. Гетьманчук // Світло. - 1911. - № 4. - С. 59.

9. Готалов-Готлиб А. Современные педагогические течения / А. Готалов-Готлиб. Херсон: Б. и., 1925. - 193 с.

10. Григорьев В. Исторический очерк русской школы / В. Григорьев. - М., 1900. $587 \mathrm{c}$.

11. Гринченко Б. На беспросветном пути / Б. Гринченко. - Киев, 1906. - С. 14.

12. Гриценко М. Історія педагогіки / М. Гриценко. - К., 1973. - 448 с.

13. Добрянський І., Постолатій В. / І. Добрянський, В. Постолатій Громадська приватна ініціатива з розвитку освіти України (кінець XIX - початку XX ст.). - Кіровоград, 1998. - 143 c.

14. Документы, известия и заметки // Киевская старина. - 1905. - № 3. - С. 23-27.

15. Егоров С. Теоретические проблемы содержания школьного образования в педагогике России конца XIX - начала XX века / С. Егоров // Вопросы истории школы и педагогики в дореволюционной России. - М.: Издательство АПН, 1978. - С. 22-37.

16. Земская хроника // Сборник Херсонского губернского земства. - 1901. - Май. C. 212.

17. Исторический очерк г. Елисаветграда / Сост. А. Пашутин. - Елисаветград, 1897. $-176 \mathrm{c}$.

18. Каменев С. Церковь и просвещение в России / С. Каменев. - М.: Атеист, 1929. $-161 \mathrm{c}$.

19. Каптерев П. История русской педагогики / П. Каптерев. - СПб., 1909. $380 \mathrm{c}$.

20. Конощенко А. До історії земської школи на Херсонщині (згадки, нариси, матеріали). - К.: Б. в., 1908. - 32 с.

21. Константинов Н., Струминский В. Очерки по истории начального образования в России / Н. Константинов, В. Струминский. - М., 1953. - 479 с.

22. Корф Н. Парижская всемирная выставка / Н. Корф // Народная школа. - 1878. Ч. $12 .-$ C. 20.

23. Корф Н. Русская начальная школа. Руководство для земских гласных и учителей земских школ / Н. Корф. - СПб., 1870. - 349 с.

24. Миропольский С. Очерк истории церковно-приходской школы от первого ее возникновения на Руси до настоящего времени / С. Миропольский. - Вып. 3. СПб., 1895. $-144 \mathrm{c}$.

25. Нестеренко П. Корф М. О. і національна українська школа / П. Нестеренко // Записки Одеського наукового товариства. Секція педагогічна. № 1. - Одеса, 1930.

26. Рождественский С. Исторический обзор деятельности Министерства народного просвещения: 1802 -1902 / С. Рождественский. - СПб., 1912. - 512 с.

27. Русова С. Нова школа / С. Русова // Світло. - 1914. - № 7, 8. - С. 13-14.

28. Сірополко С. Школа і книжка / С. Сірополко // Світло. - 1910. - № 12.

29. Справа народної освіти на Україні // Світло. - 1911. - Вересень. - С. 52.

30. Фармаковский В. Начальная школа Министерства народного просвещения / В. Фармаковский. - СПб., 1900. - 200 с. 
31. Чарнолуский В. Земство и народное образование / В. Чарнолуский. - СПб., 1911. $-345 \mathrm{c}$.

32. Чепіга Я. Проект Української школи / Я. Чепіга // Світло. - 1914. - № 4. - С. 20.

33. Черниговец. Вопросы о народном языке в школе / Черниговец // Южные записки. - 1904. - № 12. - С. 15.

34. Шафрановський В., Фазан В. Питання дисципліни в церковно-парафіяльних школах XIX- початку XX століть / В. Шафрановський, В. Фазан // Шкільна родина. 2021. - № 1 (196). - C. 82-84. - DOI: https://doi.org/10.33272/2522-9729-2021-1(196)-82-84

\title{
ШКОЛЬНОЕ РЕЛИГИОЗНОЕ ОБРАЗОВАНИЕ НА ТЕРРИТОРИИ ЮЖНОЙ УКРАИНЫ В ТЕЧЕНИЕ ХІХ ВЕКА
}

\author{
Волос Ольга, \\ кандидат исторических наук, \\ дочент кафедры философии образования, \\ теории и методики обществоведческих предметов \\ Николаевский областной институт \\ последипломного педагогического образования \\ ул. Адмиральская, 4-а, 54001, Николаев, Украина \\ olha.volos@moippo.mk.ua
}

В статье рассматривается вопрос преподавания «Закона Божьего» в системе народного образования на территории Украины. Анализируется структура курса и отдельные методические аспекты преподавания. Выясняется государственная политика по внедрению «Закона Божьего» в учебный проиесс в течение XIX века. Раскрывается земская политика относительно религиозного образования и воспитания. Освещается мнение передовой педагогической общественности Украины относительно этой проблемы. Исследуется источниковедческая база этой проблемы.

Ключевые слова: Закон Божий; законоучитель; земство; народная школа; педагогическая общественность; южная Украина.

\section{RELIGIOUS EDUCATION IN SCHOOLS OF SOUTHERN UKRAINE DURING THE XIX CENTURY}

\author{
Volos Olga, \\ Candidate of Historical Sciences (Ph.D.) \\ Department of education philosophy and social studies \\ In-Service Teachers Training Institute \\ 4-a Admiralska Street \\ Mykolaiv, 54001, Ukraine \\ olha.volos@moippo.mk.ua
}

The article discusses the process of the school ethical course (Scripture of Knowledge) in the XIX - the beginning of the XX century. Approaches to selecting content, course structure, and teaching methods are considered. It is concluded that at the beginning of the XX century the legislative base for such course was created and it determined the aim, structure, laws, and duties. Innovative teachers (catechists) took up the position of course integration, struggled with formalism and dogmatism in their teaching.

The article deals with the issue of teaching the "God's law» within the public education system in Ukraine. The article analyzes the course structure and some methodological aspects 
of teaching, it clarifies the state policy regarding the place of "God's law» in the learning process. The article highlights the opinion of the advanced pedagogical community of Ukraine regarding this issue.

The author of the article offers an understanding of the regions' role in the development of public education, she also highlights the essential features of Ukrainian schools. The article proves that the local communities' activity has provided a quantitative and qualitative shift in the Ukrainian school system, ensured understanding of education as a fundamental human right and as a way of improving the quality of life.

Keywords: God's Law; local communities of southern Ukraine; pedagogical community; public school; religious teacher.

\section{REFERENCES}

1. Anastasiev, A. (1915). Narodnaja shkola: Rukovodstvo dlja uchitelej i uchitel'nic [Folk School: A Guide for Teachers and Female Teachers]. M. (rus).

2. Bobrov, V. (2001). Stanovlennia ta rozvytok litseiv i himnazii Pivdnia Ukrainy (XIX-poch. XX st.) [Formation and development of lyceums and gymnasiums of the South of Ukraine (XIX - early XX centuries). Kherson (ukr).

3.Bogdanov, I. (1964). Gramotnost' $i$ obrazovanie v dorevoljucionnoj Rossii i SSSR (istoriko-statisticheskie ocherki): Statistika [Literacy and Education in Pre-Revolutionary Russia and the USSR (Historical and Statistical Essays): Statistics]. M. (rus).

4. Charnoluskij, V. (1911). Zemstvo i narodnoe obrazovanie [Zemstvo and public education]. SPb., 1911 (rus).

5. Chepiha, Ya. (1914). Proekt Ukrainskoi shkoly [The project of the Ukrainian school]. Svitlo, 4, 20 (ukr).

6. Chernigovec. (1904). Voprosy o narodnom jazyke v shkole [Questions about the vernacular at school]. Juzhnye zapiski, 12, 15 (rus).

7. Dobriansky, I. \& Postolatii, V. (1998). Hromadska pryvatna initsiatyva z rozvytku osvity Ukrainy (kinets XIX - pochatku XX st.) [Public private initiative for the development of education in Ukraine (late nineteenth - early twentieth century)]. Kirovohrad (ukr).

8. Dokumenty, izvestiya i zametki. (1905). [Documents, news and notes]. Kievskaya starina, 3, 23-27 (rus).

9. Farmakovskij, V. (1900). Nachal'naja shkola Ministerstva narodnogo prosveshhenija [Primary School of the Ministry of Public Education]. SPb. (rus).

10. Gotalov-Gotlib, A. (1925). Sovremennye pedagogicheskie techenija [Modern pedagogical currents]. Herson: B. i. (rus).

11. Grigor'ev, V. (1900). Istoricheskij ocherk russkoj shkoly [Historical sketch of the Russian school]. M. (rus).

12. Grinchenko, B. (1906). Na besprosvetnom puti [On a hopeless path]. Kiev (rus).

13. Hetmanchuk, Ya. (1911). Nashi spodivannia [Our hopes]. Svitlo, 4, 59 (ukr).

14. Pashutin, A. (Comp.) (1897). Istoricheskij ocherk g. Elisavetgrada [Historical sketch of Elisavetgrad]. Elisavetgrad (rus).

15. Hrytsenko, M. (1973). Istoriia pedahohiky [History of pedagogy]. K. (ukr).

16. Kamenev, S. (1929). Cerkov i prosveshenie v Rossii [The Church and Enlightenment in Russia]. M: Atheist (rus).

17. Kapterev, P. (1909). Istoriya russkoj pedagogiki [History of Russian Pedagogy]. St. Petersburg (rus).

18. Konoshchenko, A. (1908). Do istorii zemskoi shkoly na Khersonshchyni (zghadky, narysy, materialy) [To the history of the Zemstvo school in the Kherson region (mentions, 
essays, materials)]. K.: B. v. (ukr).

19. Konstantinov, N. \& Struminskij, V. (1953). Ocherki po istorii nachal'nogo obrazovanija $v$ Rossii [Essays on the history of primary education in Russia]. M. (rus).

20. Korf, N. (1878). Parizhskaja vsemirnaja vystavka [Paris World Exhibition]. Narodnaja shkola, Ch. 12, 20 (rus).

21. Korf, N. (1870). Russkaja nachal'naja shkola. Rukovodstvo dlja zemskih glasnih $i$ uchitelej zemskih shkol [Russian primary school. A guide for zemstvo vowels and zemstvo school teachers]. SPb. (rus).

22. Miropol'skij, S. (1895). Ocherk istorii cerkovno-prihodskoj shkoly ot pervogo ee vozniknovenija na Rusi do nastojashhego vremeni [Essay on the history of the parish school from its first appearance in Russia to the present]. Vyp. 3. SPb. (rus).

23. Nesterenko, P. (1930). Korf M. O. i natsionalna ukrainska shkola [Korf M. O. and the national Ukrainian school]. Zapysky Odeskoho naukovoho tovarystva. Sektsiia pedahohichna, 1. Odesa (ukr).

24. Rozhdestvenskij, S. (1912). Istoricheskij obzor dejatel'nosti Ministerstva narodnogo prosveshhenija: 1802-1902 [Historical review of the activities of the Ministry of Public Education: 1802-1902]. SPb. (rus).

25. Rusova, S. (1914). Nova shkola [New school]. Svitlo, 7, 8, 13-14 (ukr).

26.Shafranovskyi, V. \& Fazan, V. (2021). Pytannia dystsypliny v tserkovno-parafiialnykh shkolakh XIX - pochatku XX stolit [Questions of discipline in church-parish schools of the XIX - early XX centuries]. Shkilna rodyna, 1 (196), 82-84.-DOI: https://doi.org/10.33272/25229729-2021-1(196)-82-84 (ukr).

27. Siropolko, S. (1910). Shkola i knyzhka [School and book]. Svitlo, 12 (ukr).

28. Sprava narodnoi osvity na Ukraini. (1911). [The cause of public education in Ukraine]. Svitlo. Veresen, 52 (ukr).

29. Vanchakov, A. (1908). Zametki o nachal'noj cerkovnoj shkole (Vvidu proekta zakona o vseobshhem obuchenii) [Church Elementary School Notes (In view of the Universal Education Bill)]. SPb. (rus).

30. Veselovskij, B. (1909). Istorija zemstv za sorok let [Zemstvo history for forty years]. T. 1. Spb. (rus).

31. Volos, O. (1996). Rol povitovykh zemstv Khersonskoi hubernii v stanovlenni narodnoi osvity nashoho kraiu (60-ti roky XIX - poch. XX st.) [The role of county zemstvos of Kherson province in the formation of public education of our region (60s of the XIX - early XX centuries)]. Veresen, 1, 19 (ukr).

32. Vostorgov, I. (1911). Gosudarstvennaja Duma i cerkovnye shkoly. Besplatnoe prilozhenie k zh-lu "Narodnoe obrazovanie» za sentjabr' $1911 \mathrm{~g}$. [State Duma and church schools. Free supplement to magazine «Public Education» for September 1911]. SPb. (rus).

33. Yegorov, S. (1978). Teoreticheskie problemy soderzhaniya shkolnogo obrazovaniya v pedagogike Rossii konca XIX - nachala XX veka. [Theoretical problems of the content of school education in the pedagogy of Russia of the late XIX - early XX century]. Voprosy istorii shkoly i pedagogiki v dorevolyucionnoj Rossii. Moscow: APN Publishing House (rus).

34. Zemskaya chronika. (1901). [Zemsky Chronicle]. Sbornik Khersonskogo gubernskogo zemstvo. May, 212 (rus). 